\title{
Analisis Viabilitas Spermatozoa Sapi Friesian Holstein (Bos taurus) Post Thawing Semen Beku Dengan Pengaruh Suhu dan Lama Waktu Thawing Berbeda \\ Spermatozoa Viability Analysis of Post Thawing Semen of the Friesian Holstein Cow (Bos taurus) with Different Effects of Temperature and Length of Thawing Time
}

\author{
Dewi Malinda $^{1 *}$, Hari Santoso ${ }^{2 * *}$, Husain Latuconsina ${ }^{3}$ \\ 1,2,3 Jurusan Biologi, F-MIPA Universitas Islam Malang, Indonesia
}

\begin{abstract}
ABSTRAK
Prinsip pembekuan semen adalah untuk mempertahankan kelangsungan hidup sperma dalam jangka waktu yang lama (long term preservation). Thawing adalah proses pencairan kembali semen beku sapi sebelum digunakan dalam proses inseminasi buatan (IB). Pencairan ini memiliki pengaruh besar pada keadaan sperma, terutama pada integritas sperma dalam semen, tergantung pada suhu dan lamanya waktu. Pemilihan suhu dan lama waktu thawing yang baik dan tepat dapat mencegah kerusakan spermatozoa. Tujuan penelitian untuk menganalisa pengaruh perbedaan suhu dan lama waktu post thawing terhadap viabilitas spermatozoa sapi FH (Frisian Holstein) dan mencari suhu dan lama waktu thawing yang optimal dalam proses IB. Metode penelitian dilakukan secara eksperimental menggunakan RAK dengan 3 perlakuan kelompok dan 2x ulangan. Bahan penelitian menggunakan semen beku sapi FH dari Balai Besar Inseminasi Buatan (BBIB) Singosari. Variabel yang diamati adalah Viabilitas dengan pewarnaan Eosin 2\%. Analisis data mengguakan uji ANOVA Faktorial. Hasil penelitian diperoleh lama waktu thawing tidak berbeda secara signifikan yaitu $\mathrm{P}>0,05$, suhu $25^{\circ} \mathrm{C} 20$ detik : $66,30 \%, 25^{\circ} \mathrm{C} 30$ detik : $66,80 \%, 25^{\circ} \mathrm{C} 40$ detik : $63,30 \%, 37^{\circ} \mathrm{C} 20$ detik $: 65,00 \%, 37^{\circ} \mathrm{C} 30$ detik :74,30\%, $37^{\circ} \mathrm{C} 40$ detik : $69,00 \%, 40^{\circ} \mathrm{C} 20$ detik : $75,50 \%, 40^{\circ} \mathrm{C} 30$ detik : 65,50\%, 40 ${ }^{\circ} \mathrm{C} 40$ detik: 67,50\%, presentase hidup (Viabilitas) spermatozoa tertinggi terdapat pada suhu $40^{\circ} \mathrm{C}$ dengan lama waktu 20 detik dengan nilai $75,50 \%$. Semakin tinggi suhu dengan waktu thawing yang singkat dapat mendukung tingginya viabilitas.
\end{abstract}

Kata Kunci: Bos taurus, Semen beku, Thawing, Viabilitas Spermatozoa

\section{ABSTRACT}

The principle of freezing semen is to maintain the survival of sperm in the long term (long term preservation). Thawing is the process of thawing frozen cattle semen before it is used in the artificial insemination process (IB). This thawing has a big influence on the state of sperm, especially on the integrity of sperm in semen, depending on the temperature and length of time. The choice of temperature and length of time thawing is good and right can prevent damage to spermatozoa. The purpose of this study was to analyze the effect of differences in temperature and the length of post thawing time on the viability of FH (Frisian Holstein) cow spermatozoa and to find the optimal temperature and length of thawing time in the IB process. The research method was experimental using $R A K$ with 3 treatment groups and $2 x$ replications. The research material used frozen semen of FH cattle from the Singosari Center for Artificial Insemination (BBIB). The observed variable was Viability with Eosin staining of 2\%. Data analysis used the Factorial ANOVA test. The results of this study are the length of time thawing did not differ significantly namely $P>0.05$, temperature $25^{\circ} \mathrm{C} 20$ seconds: $66.30 \%, 25^{\circ} \mathrm{C} 30$ seconds: $66.80 \%, 25^{\circ} \mathrm{C} 40$ seconds: $63,30 \%, 37^{\circ} \mathrm{C} 20$ seconds: $65.00 \%, 37^{\circ} \mathrm{C} 30$ seconds: $74.30 \%, 37^{\circ} \mathrm{C}$ 40 seconds: $69.00 \%, 40{ }^{\circ} \mathrm{C} 20$ seconds: $75.50 \%, 40{ }^{\circ} \mathrm{C} 30$ seconds: $65.50 \%, 40{ }^{\circ} \mathrm{C} 40$ seconds: $67.50 \%$, the highest percentage of life (viability) of spermatozoa is at $40^{\circ} \mathrm{C}$ with a duration of 20 seconds with a value of $75.50 \%$. Conclusions the higher temperature with the short thawing time can support the high viability.

Keywords: Bos taurus, Frozen semen, Thawing, Spermatozoa Viability

*) Dewi Malinda, Jurusan Biologi, Jurusan Biologi FMIPA UNISMA, J1. MT Haryono 193, Malang 65144, Telp. 085807287530, email: dewimalinda52.dm@gmail.com

**) Drs. Hari Santoso, M.Biomed. Jurusan Biologi, Jurusan Biologi FMIPA UNISMA, Jl. MT Haryono 193, Malang 65144, email: harisantoso.m.biomed@gmail.com

Diterima Tanggal 15 Agustus 2019 - Dipublikasikan Tanggal 25 Januari 2021 


\section{Pendahuluan}

Sapi FH (Frisian Holstein) adalah sapi yang berasal dari provinsi Belanda Utara dan provinsi Friesland Barat. Ciri-ciri sapi FH adalahberbadan besar karena nafsu makan tinggi dan untuk sapi betina memiliki ambing yang besar. Berkepala panjang dan bertanduk kecil mengarah kedepan dan membengkok ke dalam [1].

Semen adalah hasil dari metabolisme organ reproduksi ternak jantan yang nantinya akan diejakulasi melalui penis untuk disalurkan ke dalam saluran kelamin betina pada saat terjadi kopulasi. Seiring dengan kemajuan teknologi, semen dapat ditampung dengan beberapa cara untuk keperluan IB [2]. Spermatozoa merupakan komponen yang paling penting pada semen, sedangkan selain spermatozoa, semen juga terdiri dari plasma semen. Fungsi utama dari spermatozoa adalah untuk membuahi ovum [3].

Viabilitas merupakan presentase hidup sel spermatozoa yang ditandai dengan sedikit sekali bahkan tidak menyerap warna Eosin $2 \%$ sedangan sel sperma yang sudah mati akan mengambil warna karena permeabilitas dinding meningkat sewaktu mati [4].

Thawing merupakan proses pencairan kembali semen yang telah dibekukan sebelum digunakan untuk kegiatan inseminasi buatan. Lama waktu dan suhu thawing berpengaruh nyata terhadap kualitas spermatozoa, khususnya terhadap kelengkapan sel spermatozoa pada semen. Semen yang berkualitas sangat diperlukan pada program IB. Penilaian semen yang baik untuk inseminasi buatan tidak hanya dilihat secara kualitas tapi juga kuantitasnya, pada saat sebelum dibekukan maupun sesudah dibekukan. Suhu thawing yang sesuai di harapkan dapat mencegah kerusakan dari sel spermatozoa. Sehingga spermatozoa tetap memiliki kemampuan yang tinggi untuk membuahi ovum [5].

Cara pelaksanaan thawing yang berkembang dilapangan sangat beragam. Suhu thawing yang diatas $37^{\circ} \mathrm{C}$ diharapkan dapat meningkatkan motilitas atau viabilitas dari spermatozoa. Namun, apabila melebihi batas, waktu optimal justru akan merusak sel spermatozoa [6]. Nilai tertinggi dari presentase motilitas didapatkan dari suhu thawing $37^{\circ} \mathrm{C}$ [7]. Suhu yang tinggi dalam media yang nantinya digunakan untuk thawing dapat mengakibatkan siklus metabolisme spermatozoa meninggi sehingga memerlukan energi yang tinggi pula [8].

Suhu thawing berpengaruh terhadap viabilitas spermatozoa sapi FH (Friesian Holstein), di mana semakin tinggi suhu Thawing $\left(46^{\circ} \mathrm{C}\right)$ justu semakin menurunkan presentase motilitas spermatozoa [9]. Hal ini menunjukkan bahwa terdapat kisaran suhu thawing yang optimal untuk mendukung motilitas spermarotozoa. Selanjutnya mendapatkan suhu thawing $25^{\circ} \mathrm{C}$ masih layak untuk IB karena masih mendukung tingginya motilitas spermatozoa $41 \%, 40 \%$ adalah presentase minimal spermatozoa motil setelah thawing [10].

Merujuk kepada hasil penelitian yang telah dilakukan, maka perlu dilakukan pengujian viabilitas spermatozoa post thawing dari semen beku khususnya pada sapi FH (Friesian Holstein) menggunakan suhu thawing dan lama waktu yang berbeda agar dapat mengetahui pengaruh suhu dan lama waktu thawing terhadap viabilitas spermatozoa semen beku sekaligus mengetahui suhu dan lama waktu thawing yang ideal untuk mendukung viabilitas spermatozoa sapi FH (Friesian Holstein).

\section{Material dan Metode}

\section{Bahan dan Alat}

Bahan yang digunakan dalam penelitian ini adalah semen beku sapi FH (Frisian Holstein), alcohol, Eosin $2 \%$, air suhu $\left(25^{\circ} \mathrm{C}, 37^{\circ} \mathrm{C}\right.$ dan $\left.40{ }^{\circ} \mathrm{C}\right)$.

Alat yang digunakan pada penelitian adalah mikroskop electron, gelas objek dan gelas penutup, cuvet, erlenmeyer, gelas ukur, spuit, mikropipet, camera handphond, stopwatch.

\section{Metode}

Jenis penelitian yang dilakukan adalah penelitian menggunakan metoda random sampling dari sperma beku yang tersedia. Metoda random sampling dilakukan dengan cara mengambil sperma dari sapi FH (Friesian Holstein) yang telah di bekukan. Penelitian ini menggunakan Rancangan Acak Kelompok (RAK) yang terdiri dari 3 perlakuan, 3 kelompok dan 2 ulangan. 


\section{Cara Kerja}

Penampungan semen dilakukan dengan AV ( Artifical Vagina). Setelah lolos uji semen segar dan telah diencerkan menggunakan tris kuning telur selanjutnya dilakukan uji BF (Before Freezing). Selanjutnya semen yang lolos uji BF akan dilakukan print straw untuk memasukkan semen yang akan dibekukan. Sebelum dilakukan proses freezing, yaitu dilakukan dengan N2 Cair dalam storage container maka dilakukan proses prefreezing dalam digit cool. Tahap PTM (Post Thawing Motility) dilakukan dengan perlakuan 3 suhu yang berbeda yaitu $25^{\circ} \mathrm{C}, 37^{\circ} \mathrm{C}$ dan $40^{\circ} \mathrm{C}$ dan 3 waktu yaitu 20 , 30 dan 40 detik. Presentase spermatozoa yang hidup dapat dihitung menggunakan rumus [11] sebagai berikut:

$$
\text { Rumus } \% \text { sperma hidup }=\frac{\text { jumlah spermatozoa yang hidup }}{\text { jumlah total sel spermatozoa }} \times 100 \%
$$

Analisis Data: Analisis yang digunakan untuk mengetahui apakah ada perbedaan yang signifikan atau tidak terhadap Presentase hidup (Viabilitas) spermatozoa dengan menggunakan uji ANOVA Faktorial dari dua factor yaitu suhu dan lama waktu Thawing dengan taraf signifikan 5\% [12].

\section{Hasil dan Diskusi}

Pengamatan Viabilitas Spermatozoa Post Thawing Semen Beku Sapi FH (Frisian Holstein): Dari penelitian yang telah dilakukan di dapatkan hasil presentase viabilitas spermatozoa semen beku sapi FH (Frisian Holstein) pada Tabel 1.

Tabel 1. Presentase Viabilitas Spermatozoa Semen Beku Sapi FH (Frisian Holstein) dengan suhu dan lama waktu thawing yang berbeda

\begin{tabular}{|c|c|c|c|c|c|}
\hline \multicolumn{2}{|c|}{ Perlakuan } & \multicolumn{2}{|c|}{ Ulangan } & \multirow{2}{*}{$\begin{array}{c}\text { Total } \\
(\%)\end{array}$} & \multirow{2}{*}{$\begin{array}{c}\text { Rata-rata } \\
(\%)\end{array}$} \\
\hline $\begin{array}{c}\text { Suhu thawing } \\
\left({ }^{\circ} \mathrm{C}\right)\end{array}$ & $\begin{array}{l}\text { Lama thawing } \\
\text { (Detik) }\end{array}$ & $\mathrm{I}(\%)$ & II (\%) & & \\
\hline \multirow{3}{*}{25} & 20 & 59 & 74 & 133 & 66,30 \\
\hline & 30 & 65,50 & 68 & 133,5 & 66,80 \\
\hline & 40 & 68,5 & 56 & 124,5 & 63,30 \\
\hline \multirow{3}{*}{37} & 20 & 67 & 63 & 130 & 65,00 \\
\hline & 30 & 70 & 78,50 & 148.5 & 74,30 \\
\hline & 40 & 68,50 & 69,50 & 138 & 69,00 \\
\hline \multirow{3}{*}{40} & 20 & 76 & 75 & 151 & 75,50 \\
\hline & 30 & 65,50 & 65,50 & 131 & 65,50 \\
\hline & 40 & 69 & 66 & 135 & 67,50 \\
\hline
\end{tabular}

Hasil viabilitas tertinggi di dapatkan pada perlakuan T3t1 dengan menggunakan suhu $40^{\circ} \mathrm{C}$ pada waktu thawing selama 20 detik dengan nilai $75,50 \%$ dan viabilitas terendah terdapat pada suhu $25^{\circ} \mathrm{C}$ dengan lama waktu thawing 40 detik sebesar $63,30 \%$. Semakin cepat tingkat perubahan selama pencairan, semakin banyak sperma yang layak hidup. Ini dapat dicapai pada saat melakukan proses pencairan menggunakan suhu air pencairan yang sangat tinggi [13]. Juga kecepatan (waktu) perubahan selama thawing akan mengurangi tekanan terhadap spermatozoa karena spermatozoa melewati massa kritis (fasa transisi) dengan cepat pula sehingga spermatozoa yang hidup dan normal akan menjadi lebih banyak dan akibatnya angka konsepsi menjadi lebih baik. Juga, laju perubahan waktu selama pencairan mengurangi tekanan pada sperma ketika sperma melewati massa kritis (fase 
e-Jurnal Ilmiah BIOSAINTROPIS (BIOSCIENCE-TROPIC)

Volume 6/ No.: 2 / Halaman 46 - 51/ Januari Tahun 2021

ISSN : 2460-9455 (e) - 2338-2805(p)

transisi) dengan cepat, sehingga menghasilkan lebih banyak sperma normal yang hidup, yang menjadikan tingkat konsepsi membaik. Penelitian yang telah dilakukan juga menemukan bahwa melakukan thawing semen dengan menggunakan temperature $40^{\circ} \mathrm{C}$ dapat menghasilkan motilitas dan daya hidup yang normal dan lebih tinggi dibandingkan melakukan thawing semen beku pada temperature $17^{\circ} \mathrm{C}, 5^{\circ} \mathrm{C}, 21^{\circ} \mathrm{C}$ [14].

Dalam penelitian ini, percobaan dengan pewarna eosin dapat membedakan sperma yang mati dan masih hidup. Sperma yang mati ditunjukkan dengan kepala sperma berwarna, dan sperma yang hidup ditunjukkan dengan kepala sperma yang menyerap sedikit atau tanpa warna. Hal ini dapat disebabkan ketika eosin bersentuhan langsung dengan sperma yang masih hidup maka cairan eosin ini tidak dapat menembus ke dalam sel sperma yang disebabkan membran sperma impermiable terhadap pewarna eosin, sedangkan pada sperma yang sudah mati selaput membrannya telah rusak, maka eosin dapat masuk ke sel sperma dengan mudah [15].

Pengaruh Suhu dan Lama Waktu Thawing Terhadap Presentase Viabilitas Spermatozoa Sapi FH (Friesian Holstein): Adapun hasil analisis yang telah dilakukan dengan menggunakan uji ANOVA faktorial seperti yang telah ditampilkan pada Tabel 2, menunjukkan bahwa hasil yang diperoleh tidak terdapat efek yang nyata atau tidak signifikan antara suhu dan lama waktu thawing karena nilai $\mathrm{P}>0,05$. Hal ini diperkirakan karena pemilihan suhu dan waktu yang relatif aman digunakan untuk Thawing pada saat akan melakukan IB .Pada suhu $25^{\circ} \mathrm{C}$ mendapatkan nilai diatas standart SNI yaitu diatas $50 \%$, lama waktu thawing yang terbaik pada suhu $25^{\circ} \mathrm{C}$ adalah 30 detik dengan nilai rata-rata $66,80 \%$, untuk itu suhu tersebut juga sering dipakai oleh orang yang hendak melakukan IB. Viabilitas normal spermatozoa yang dipakai IB membutuhkan $50 \%$ spermatozoa motil dan hidup [16]. Thawing di Negara Indonesia dilakukan dengan memakai air ledeng pada $15^{\circ} \mathrm{C}$ hingga $25^{\circ} \mathrm{C}$ selama 15 detik.. Suhu thawing $25^{\circ} \mathrm{C}$ masih layak untuk IB karena masih mendukung tingginya motilitas spermatozoa $41 \%$ dimana jika motilitas tinggi maka nilai viabilitas juga otomatis tinggi. Oleh karena itu pada suhu $25^{\circ} \mathrm{C}$ yang menggunakan air kran atau air sumur itu boleh digunakan sebagai thawing dan harus menggunakan lama waktu thawing yang tepat [17].

Tabel 2. Hasil uji ANOVA Viabilitas Spermatozoa Sapi FH (Friesian Holstein) Pada Perlakuan Suhu dan Lama Waktu Thawing

\begin{tabular}{llllll}
\hline & $\begin{array}{l}\text { Jumlah } \\
\text { Kuadrat }\end{array}$ & db & $\begin{array}{l}\text { Kuadrat } \\
\text { Tengah }\end{array}$ & F & P \\
\hline Suhu & 76.6 & 2 & 38.3 & 1.373 & 0.302 \\
Waktu & 27.6 & 2 & 13.8 & 0.495 & 0.626 \\
Suhu+Waktu & 194.8 & 4 & 48.7 & 1.747 & 0.224 \\
Residuals & 251.0 & 9 & 27.9 & & \\
\hline
\end{tabular}

Pada penelitian ini suhu $37^{\circ} \mathrm{C}$ mendapatkan nilai yang tinggi dengan lama waktu 30 detik dengan nilai 74,30\% hal ini sesuai standart SNI 4869-1:2017 yang menyatakan bahwa pada tahapan ini di BBIB Singosari semen beku yang telah dicairkan kembali (thawing) pada suhu antara $37^{\circ} \mathrm{C}-38^{\circ} \mathrm{C}$ selama 30 detik semen beku yang telah dicairkan tersebut harus menunjukkan nilai motilitas spermatozoa minimal $40 \%$ dan gerakan individu spermatozoa minimal skor 2 (dua) dan jumlah sel spermatozoa minimum 25 juta perdosis. Pencairan di atas $37^{\circ} \mathrm{C}$ dapat meningkatkan viabilitas spermatozoa, tetapi jika melebihi batas waktu kritis bisa mematikan sel spermatozoa. Dalam studi lain, persentase viabilitas semen beku seekor kerbau bernama sapi Ravi Nilli berkurang pada saat pencairan yang durasinya semakin lama dimana viabilitas tertinggi yaitu pada durasi thawing 30 detik 
e-Jurnal Ilmiah BIOSAINTROPIS (BIOSCIENCE-TROPIC)

Volume 6/ No.: 2 / Halaman 46 - 51/ Januari Tahun 2021

ISSN : 2460-9455 (e) - 2338-2805(p)

pada air bersuhu $37^{\circ} \mathrm{C}$ sebesar $79,3 \%$ dan menurun menjadi $77,0 \%$ pada durasi thawing 60 detik pada air bersuhu $37^{\circ} \mathrm{C}$. Suhu thawing dengan lama waktu yang tidak sesuai dapat merusak selaput sperma akibat tekanan panas dan kontak dengan oksigen. Membran spermatozoa yang tersusun dari fosfolipid mengalami reduksi karena munculnya asam lemak dari proses peroksidasi sel [18]. Thawing dalam air $37 \mathrm{C}$ untuk jangka waktu 15 detik tidak menciptakan tekanan osmotik yang ekstrim dalam membran sperma, sehingga tidak mengganggu permeabilitas membran. Hal ni menjamin keseimbangan yang baik antara fluiditas membran sel dan homeostasis untuk pertukaran senyawa yang normal. Selain itu, karena durasi thawing yang singkat, maka tidak ada peningkatan aktivitas metabolisme sperma dan tidak ada penurunan tingkat kelangsungan hidup spermatozoa[19].

Perubahan yang lebih cepat pada suhu thawing dapat menurunkan tekanan sperma dan memungkinkannya dengan cepat melewati periode ketidakstabilan (stabilitas), hal ini memungkinkan lebih banyak sperma untuk tetap hidup dan normal. Sperma masih hidup dan dapat digunakan lebih efektif karena waktu yang digunakan pada saat thawing lebih singkat. Suhu dan waktu pencairan memiliki pengaruh besar pada kondisi sperma, terutama integritas sperma dalam semen. Kombinasi suhu dan lama waktu pencairan yang baik adalah yang dapat menyebabkan sedikit atau tidak ada kerusakan pada sel spermatozoa, sehingga memiliki kemampuan untuk mebuahi ovum yang tinggi [20].

\section{Kesimpulan}

Semakin tinggi suhu thawing dengan waktu yang semakin singkat dapat mendukung tingginya nilai viabilitas spermatozoa semen beku. Presentase hidup spermatozoa (Viabilitas) tertinggi didapatkan pada suhu $40^{\circ} \mathrm{C}$ dan waktu 20 detik dengan nilai $75,50 \%$.

\section{Ucapan Terima Kasih}

Penulis mengucapkan terima kasih kepada Balai Besar Inseminasi Buatan (BBIB) Singosari yang telah mengarahkan hingga penelitian ini selesai.

\section{Daftar Pustaka}

[1] Syarif .Z.,dan Sumoprastowo. 1985. Ternak Perah. CV. Yasaguna. Jakarta

[2] Toelihere, M. R. 1993. Inseminasi Buatan Pada Ternak. Penerbit Angkasa. Bandung.

[3] Djanuar. 1985. Fisiologi Reproduksi dan Inseminasi Buata pada sapi. Gadjah Mada University Press, Yogyakarta.

[4] Hafez, E. S. E. 1987. Reproduction in Farm Animal, 4th Edition, Lea and Fibiger. Philadelfia, USA.

[5] Zelpina E., Bayu R., dan Sumarsono T. 2012. Kualitas Spermatozoa Post Thawing dari Semen Beku Sapi Perah. Fakultas Peternakan Universitas Jambi. Jambi.

[6] Deka, B.C. and Rao, A. R. 1987. Effect of extenders and thawing methods on post thawing preservation of goat semen. Indian Vet.J. 64:591-594.

[7] Pace, M.M, Sullivan, J.J., Elliot, F.I., Graham, E.F. and Coulter, G.H. 1981.Effect of thawing temperature, number of spermatozoa and spermatozoal quality on fertility of bovine spermatozoa fackaged in 0,5ml French straws. J. Anim. Sci. 53 (3) : 693701. 
e-Jurnal Ilmiah BIOSAINTROPIS (BIOSCIENCE-TROPIC)

Volume 6/ No.: 2 / Halaman 46 - 51/ Januari Tahun 2021

ISSN : 2460-9455 (e) - 2338-2805(p)

[8] Soepriondho, Y. 1985 . Pengaruh Waktu dan Suhu Thawiing Semen Beku terhadap Angka Konsepsi pada Ternak Kerbau. Tesis. Fakultas Pascasarjana Institut Pertanian Bogor. Bogor.

[9] Putri, H.P., Sumartono., Humaidah, N. 2019. Pengaruh Berbagai Suhu Thawing Terhadap Viabilitas dan Motilitas Spermatozoa Sapi FH (Friesian Holstein). Jurnal Rekastawa Peternakan. Vol.2(1): 95-98

[10] Zenichiro, K., Herliantien dan Sarastina. 2002. Teknologi Prosessing Semen Beku pada Sapi. Balai Inseminasi Buatan Singosari. Malang

[11] Susilawati, T. 2011. Spermatologi. UB Press, Malang.

[12] Syauqi,A. 2018. Comparative Study of References and Protein Quantifications Using Biuret-Spectrophotometric Method. Chimica et Natura Acta. Vol. 6 No. 2: 42-48. P-ISSN: 2355-0864 e-ISSN: 2541-2574.

[13] Chandler, J.E., Ruiz, C. F., Adkinson, R.W. and Koonce, K. L. 1984. Relationship Between Final Temperature, Thaw Rate and Quality of Bovine Semen. J. Dairy Sci. 67 (8): 1806-1812

[14] Bosrekar, M., Char, S. N., Patil, B. R. and Ranonekar, D. V.. 1984. Effect of Thawing Temperature and Time on The Forward Motility, Live Count and Acrosomal Maintenance Of Bovine Spermatozoa. Indian J. Anim. Sci. 54 (12) : 1126-1130

[15] Narato. 2009. Teknik Pengawetan dan Pewarnaan Sperma. Diakses pada tanggal 18 April 2020. URL:http://sma4rtzyoulyz. blogspot.com/2009_06_01_archive.html.

[16] Hidayatin, D. 2002. Kaji Banding Kualitas Semen Beku Produk BIBLembang dan Singosari pada Setiap Jalur Distribusi. Fakultas Kedokteran Hewan. Institut Pertanian Bogor. Bogor.

[17] Ikhsan, M. N. 1992. Manajemen Reproduksi ternak. Fakultas Peternakan Universitas Brawijaya, Malang

[18] Ansari M, Towhidil A, Moradi SM .2010. Effect Of Straw Size And Thawing Time On Quality Of Cryopreserved Buffalo Semen. Reproductive Biology.11(1)49-54.

[19] Salim, M. A., Susilawati, T., dan Wahyuningsih, S. 2012. Pengaruh Metode Thawing terhadap Kualitas Semen Beku Sapi Bali, Sapi Madura dan Sapi PO. Vol (12) No. 2: $14-19$

[20] Handiwirawan dan Fitri, Z. 1997. Penggunaan air kelapa sebagai penyeimbang fruktosa dalam pengencer terhadap kualitas sperma Sapi Simmental. Skripsi, Fakultas Pertanian Universitas Sumatera Utara, Medan. 